\title{
Atmospheric ice nuclei in the Eyjafjallajökull volcanic ash plume
}

\author{
H. Bingemer ${ }^{1}$, H. Klein ${ }^{1}$, M. Ebert ${ }^{2}$, W. Haunold ${ }^{1}$, U. Bundke ${ }^{1}$, T. Herrmann ${ }^{2}$, K. Kandler ${ }^{2}$, D. Müller-Ebert ${ }^{2}$, \\ S. Weinbruch ${ }^{2}$, A. Judt ${ }^{1}$, A. Wéber ${ }^{1}$, B. Nillius ${ }^{1}$, K. Ardon-Dryer ${ }^{3}$, Z. Levin ${ }^{3}$, and J. Curtius ${ }^{1}$ \\ ${ }^{1}$ Institute for Atmospheric and Environmental Sciences, Goethe-University, Frankfurt/M, Germany \\ ${ }^{2}$ Institute for Applied Geosciences, Technical University of Darmstadt, Germany \\ ${ }^{3}$ Department of Geophysics and Planetary Science, Tel Aviv University, Tel Aviv, Israel
}

Correspondence to: H. Bingemer (bingemer@iau.uni-frankfurt.de)

Received: 21 December 2010 - Published in Atmos. Chem. Phys. Discuss.: 24 January 2011

Revised: 15 December 2011 - Accepted: 2 January 2012 - Published: 19 January 2012

\begin{abstract}
We have sampled atmospheric ice nuclei (IN) and aerosol in Germany and in Israel during spring 2010. IN were analyzed by the static vapor diffusion chamber FRIDGE, as well as by electron microscopy. During the Eyjafjallajökull volcanic eruption of April 2010 we have measured the highest ice nucleus number concentrations $\left(>6001^{-1}\right)$ in our record of $2 \mathrm{yr}$ of daily IN measurements in central Germany. Even in Israel, located about $5000 \mathrm{~km}$ away from Iceland, IN were as high as otherwise only during desert dust storms. The fraction of aerosol activated as ice nuclei at $-18^{\circ} \mathrm{C}$ and $119 \% \mathrm{rh}_{\text {ice }}$ and the corresponding area density of ice-active sites per aerosol surface were considerably higher than what we observed during an intense outbreak of Saharan dust over Europe in May 2008.

Pure volcanic ash accounts for at least $53-68 \%$ of the 239 individual ice nucleating particles that we collected in aerosol samples from the event and analyzed by electron microscopy. Volcanic ash samples that had been collected close to the eruption site were aerosolized in the laboratory and measured by FRIDGE. Our analysis confirms the relatively poor ice nucleating efficiency (at $-18^{\circ} \mathrm{C}$ and $119 \%$ ice-saturation) of such "fresh" volcanic ash, as it had recently been found by other workers. We find that both the fraction of the aerosol that is active as ice nuclei as well as the density of ice-active sites on the aerosol surface are three orders of magnitude larger in the samples collected from ambient air during the volcanic peaks than in the aerosolized samples from the ash collected close to the eruption site. From this we conclude that the ice-nucleating properties of volcanic ash may be altered substantially by aging and processing during long-range transport in the atmosphere, and that global volcanism deserves further attention as a potential source of atmospheric ice nuclei.
\end{abstract}

\section{Introduction}

The recent eruption of the Eyjafjallajökull volcano in Iceland, besides affecting aviation in Europe, raises the question about potential effects of volcanic emissions on weather and climate. The climate impact of explosive volcanic injections into the stratosphere through the radiative effects of secondary $\mathrm{H}_{2} \mathrm{SO}_{4} / \mathrm{H}_{2} \mathrm{O}$ aerosol particles formed from the injected $\mathrm{SO}_{2}$, is well documented (Robock, 2000). However, only few eruptions reach the stratosphere, and the total emission of $20 \mathrm{Tg} \mathrm{yr}^{-1}$ of fine ash into the troposphere by small volcanic eruptions (Mather et al., 2003) exceeds the timeaveraged annual return flux of volcanic sulphate from the stratosphere to the upper troposphere by a factor of 10-40. Volcanic ash particles can affect the phase of supercooled tropospheric clouds by acting as ice nuclei (IN) (Durant et al., 2008). About $50 \%$ of the global cloud population at $-20^{\circ} \mathrm{C}$ is found to be supercooled (Choi et al., 2010), i.e. to contain metastable water that freezes upon the presence of suitable ice nuclei. Glaciation affects the phase, size distribution and colloidal stability of the cloud particles, as well as the lifetime, dimensions and radiative forcing of the clouds. Space observations show that on the planetary scale the fraction of supercooled clouds (at $-20^{\circ} \mathrm{C}$ ) and the coincident dust aerosol frequency are negatively correlated (Choi et al., 2010), likely due to glaciation by dust. Accompanying model calculations reveal that the cloud albedo is significantly affected upon glaciation.

The number concentration of atmospheric ice nuclei near the surface is monitored at the Taunus Observatory (TO) in central Germany on a daily basis since April 2008 and at Tel Aviv University (TAU) since November 2009, using the same methods and identical instruments. The data discussed here 
comprise the months of April and May 2010 that were affected by volcanic emissions from the Eyjafjallajökull eruption.

Ice nuclei remain an undersampled component of the climate system, despite of their atmospheric relevance. A quantitative assessment of their sources and a climatology of their atmospheric abundance are not available. Many components of atmospheric IN have been identified, such as minerals of desert dust, bacteria, pollen and plant debris (Pruppacher and Klett, 1997; Szyrmer and Zawadsky, 1997), although for many of them the concentrations and relevance to cloud processes are still unclear (Möhler et al., 2007; DeMott et al., 2011). In addition to these surface-derived materials, volcanism is debated as a source of atmospheric ice nuclei. However, evidence for volcanic IN from field measurements of IN so far is conflicting (Isono et al., 1959; Price and Pales, 1963; Hobbs et al., 1971; Schnell and Delany, 1976; Radke et al., 1976). Satellite observations in the South Atlantic and North Pacific (Gasso, 2008) show that natural degassing or weakly explosive volcanoes affect low marine stratocumulus for up to $1300 \mathrm{~km}$ downwind by decreasing droplet effective radius and increasing visible brightness, and may add cloud cover in otherwise cloudless areas. While these observations did not consider explicitly the ice-nucleating ability of the volcanic aerosol, Lidar measurements over central Europe during the advection of the Eyjafjallajökull volcanic ash plume observed a clear impact of ash on cloud glaciation (Seifert et al., 2011). All of the cloud layers which had cloud top temperatures below $-15^{\circ} \mathrm{C}$ contained ice. Under non-volcanic conditions such a high glaciation is found only at temperatures colder than $-25^{\circ} \mathrm{C}$ (Seifert et al., 2011). Belosi et al. (2011) measured IN in April 2010 at Bologna, Italy, using a dynamical thermal gradient chamber (Langer and Rodgers, 1975) and SEM-EDX. They found a higher IN concentration during the ash cloud transit on 20 April. About $30 \%$ of the inorganic coarse particles were of volcanic origin. However, their IN concentration of $0.71^{-1}$ (at $-18^{\circ} \mathrm{C}, \mathrm{rh}_{\text {ice }}=20.8 \%$ ) is approximately 2 orders of magnitude lower that our measurements. Our measurements of the IN number concentration with the static vapor diffusion chamber FRIDGE (Klein et al., 2010a) presented below show a significant enhancement of atmospheric IN when the dispersed ash cloud of the Eyjafjallajökull eruption reached central Europe in April 2010 and the eastern Mediterranean in May 2010. However, laboratory investigations by Hoyle et al. (2011) and Steinke et al. (2011) on two samples of sedimented fresh volcanic ash that had been collected nearby the Eyjafjallajökull crater showed a rather poor ice nucleation efficiency of the ash, except at very cold conditions $\left(<-35^{\circ} \mathrm{C}\right)$. Hoyle et al. (2011) measured the freezing temperature of bulk ash samples with a differential scanning calorimeter, and deposition and immersion nucleation on the aerosolized dust with the diffusion chamber ZINC and the Immersion Mode Cooling Chamber IMCA/ZINC, respectively. Freezing temperatures were between $-33^{\circ} \mathrm{C}$ and $-37^{\circ} \mathrm{C}$, slightly above homogeneous nu- cleation. Only a moderate effect of the ash particles on atmospheric ice nucleation was concluded. No deposition nucleation was observed for temperatures warmer than $-31{ }^{\circ} \mathrm{C}$. Part of the ash sample that was investigated by Hoyle et al. (2011) has been analyzed by Steinke et al. (2011) in the AIDA cloud chamber for its nucleating properties. They found similar results as Hoyle et al. (2011). The obvious discrepancy between our field measurements and the results from the samples collected near the crater led us to analyze the two ash samples again in our laboratory. Applying the same method to both the ambient samples and the samples generated from "fresh" ash could at least help to minimize methodical reasons for the apparent mismatch. Aliquots of the ash collected near the crater were dry dispersed, and this aerosol was sampled and analyzed by FRIDGE.

This paper is organized as follows: Sect. 2 briefly presents those methods used for our measurements, that have already been published at length elsewhere: the measurement of IN number concentration by the IN counter FRIDGE, the measurement of IN composition by the environmental scanning electron microscope ESEM, as well as the coupling between FRIDGE and ESEM. The generation of volcanic ash test aerosol samples is described. Section 3 presents number concentrations and composition of IN measured in the atmosphere over central Europe and over Israel during the period that was affected by dispersed volcanic ash in spring of 2010 . Section 4 presents our laboratory results on the nucleating efficiency of test aerosol that was produced from volcanic ash samples. In Sect. 5 we discuss the implications of the results for the atmosphere.

\section{Methods}

\subsection{Measurements of IN number concentration}

The Taunus Observatory is a site for atmospheric research located on the summit of Kleiner Feldberg ( $825 \mathrm{~m}$ a.s.1.) $25 \mathrm{~km}$ north of the city of Frankfurt. The Tel Aviv University sampling site is on the university campus, about $2.5 \mathrm{~km}$ from the Mediterranean Sea shore. The IN measurements both at the Taunus Observatory and at Tel Aviv University were done by the same methods and with instruments that were identical in construction, and have been compared by analyzing samples that were collected in parallel from the same aerosol.

For the IN measurement aerosol particles were first collected from a volume of several liters of air by electrostatic precipitation onto $47 \mathrm{~mm}$ diameter silicon substrates, and were then subsequently analyzed. The sampling efficiency of the specially designed electrostatic precipitator has been characterized in the $10-700 \mathrm{~nm}$ particle diameter range as function of sample flow rate, and is better than $94 \%$ (Klein et al., 2010a). All the samples were collected at a flow rate of $21 \mathrm{~min}^{-1}$. The total volume of air sampled was 101 at the Taunus Observatory and 51 at Tel Aviv. Substrates were 
subsequently analyzed in the isothermal static vapor diffusion chamber FRIDGE at various specified temperatures and water vapor supersaturations. In FRIDGE ice crystals are grown by deposition and condensation freezing on the ice nuclei. The ice crystals on the substrate are usually separated well from each other. It is assumed that each ice crystal represents one ice nucleus. The crystals are viewed by a CCD camera, and counted automatically. The method has been described in more detail by Klein et al. (2010a). It was intercalibrated to the continuous flow IN mixing chamber FINCH by parallel measurements of IN collected from ambient air and from test aerosol (Bundke et al., 2008). Both measurements were highly correlated at the $99.9 \%$ level. Furthermore, we have compared our method to the IN detection methods and standard applied by other experimentalists during the Fourth International Ice Nucleation Workshop ICIS2007 (Möhler et al., 2008). For this, aerosol was generated at our laboratory by dry dispersion of the same Arizona Test Dust (ATD) standard that had been used previously during ICIS-2007. Aerosol was sampled and processed by FRIDGE as described above. DeMott et al. (2011) conclude from these data (expressed as $0.1 \%$ threshold ice formation conditions, i.e. one IN per 1000 aerosol particles), that "these sample results are in good agreement with the majority of CFDC instrument results" during ICIS-2007.

In the samples from the volcanic ash event ice nucleus concentrations were measured at $-18^{\circ} \mathrm{C},-13^{\circ} \mathrm{C}$, and $-8^{\circ} \mathrm{C}$, and between $103 \%$ and $119 \%$ relative humidity over ice $\left(\mathrm{rh}_{\text {ice }}\right)$. The precision of the IN number concentration measurement by FRIDGE is $12.5 \%$ (Klein et al., 2010a). While the sampling frequency in our regular IN monitoring program is 1 sample per day, we have been collecting between 3-8 samples per day during the presence of the volcanic ash cloud at Taunus Observatory. Aerosol size spectra at Taunus Observatory were measured by a TSI 3321 Aerodynamic Particle Sizer (APS).

\subsection{Measurement of IN composition}

The chemical composition and morphology of particles that had been previously identified as ice nuclei by FRIDGE were determined by environmental scanning electron microscopy (ESEM) combined with energy-dispersive X-ray microanalysis (EDX). 239 individual particles were analyzed in four samples that were collected on the silicon substrates during the volcanically affected days of 16-17 April and 16-17 May.

The unambiguous identification of the analyzed particles as ice nuclei was enabled by a high precision laser engraved coordinate system on the substrates. Each substrate has three laser engraved, cross-shaped marks. The marks represent the coordinates 0/0, 100/0 and 0/100 of a Cartesian coordinate system on the substrate. In this way each nucleation event occurring during a FRIDGE measurement (and detectable by the visible ice crystal in the image of the CCD camera) can be documented by means of xy-coordinates, thus representing the position of the individual particle which has acted as an ice nucleus. Those marks could easily be recovered in the ESEM, and were there again used to transfer the coordinate system and thus the coordinates of all ice crystals detected by FRIDGE on the substrate to the electron microscope. The ESEM software enables to associate user-defined points (in this case the cross-shaped marks) with specific points of the positioning system of the specimen stage in the ESEM. Thus the position of ice nuclei could be recovered with an accuracy of approximately $10 \mu \mathrm{m}$. If more than one particle is observed in the field of view at the designated location, those particles are not analyzed, because it is impossible to identify the particle that served as the ice nucleus. Due to the relatively sparse distribution of particles on the substrate this was rarely the case.

Six groups of particles (Fig. 3) were distinguished: volcanic particles, soot, (aged) sea-salt, biological particles, Crich particles, metal/metal oxides. All other particles were summarized in a seventh "other" group.

The volcanic particles were classified based on the major and minor elements of the alumosilicates $(\mathrm{Mg}, \mathrm{Al}, \mathrm{Si}$, $\mathrm{K}, \mathrm{Ca}, \mathrm{Ti}$ and $\mathrm{Fe}$ ) and/or their glassy morphology. Soot is recognized by the dominant carbon signal and its characteristic morphology (e.g. Ebert et al., 2000). Biological particles (plant fibers, pollen, spores) are easily identified by their characteristic morphology. In some cases typical biological tracer elements are present in the EDX spectra besides the dominating carbon peak, like phosphorous or potassium. All carbonaceous particles, which could not be assigned to these groups were summarized in the "C-rich" group. Sea salt was classified on the base of the dominating sodium and chlorine contents. In some of these particles, chloride is partly replaced by sulphate or nitrate (aged sea salt). The group of metal/metal oxides consists predominantly of Fe-rich particles. This classification reflects the major composition of a particle. Minor compounds, which are present as coating, agglomerate or heterogeneous inclusion within individual particles were not considered for classification.

All silicate particles were classified as volcanic particles. This has to be explained in detail. The elemental composition and the morphology of the individual silicate ice nuclei fit well to the Eyjafjallajökull ashes as described by Gislason et al. (2010). But they are not an unambiguous fingerprint for volcanic material in contrast to silicate soil material. By EDX analysis it is easy to identify the silicates lying on the silicon substrates (used in the ice nucleation chamber) qualitatively, but because of the high Si-background signal it is not possible to obtain quantitative results for all major and minor elements of the silicates. In order to prove the origin of the silicate material additional impactor samples were collected on boron substrates in parallel to the FRIDGE samples. Based on elemental ratios, e.g. Si/Al-ratio, silicates from the Eyjafjallajökull plume and the "natural soil background" at Taunus Observatory can be differentiated. 


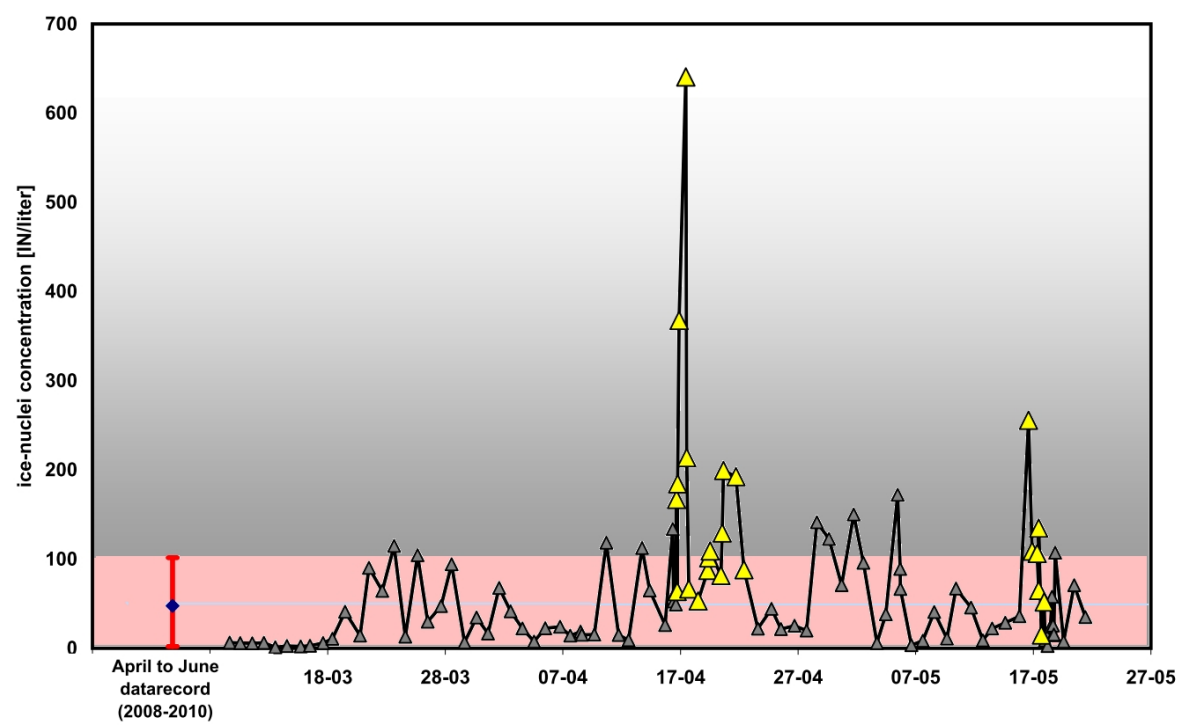

Fig. 1. Number concentration of atmospheric ice nuclei (at $-18{ }^{\circ} \mathrm{C}$ and water saturation) at the Taunus Observatory (TO) in central Germany during April-May 2010. The blue line and pink banded area are the seasonal average and standard deviation, respectively, for the months of April through June 2008-2010.

\subsection{Laboratory measurements of ice nucleating properties of volcanic ash}

We have analyzed the ice nucleating properties of aerosol produced from aliquots of the two volcanic ash samples from the 2010 eruption of Eyjafjallajökull named by Hoyle et al. (2011) "Ey0" and "Ey1". Both samples had been collected from ash sedimented to the ground. Sample "EY0" has been collected on 15 April at approximately $58 \mathrm{~km}$ downwind of the crater. Sample "Ey1" has been collected on 11 May 2010 at $8 \mathrm{~km}$ from the crater (Hoyle et al., 2011). Hoyle et al. (2011) and Steinke et al. (2011) characterize both samples in more detail. Sample "EY1" was provided by Christopher Hoyle from ETH Zurich, sample "Ey0” by Isabel Steinke from KIT Karlsruhe.

Aerosol was produced by dry dispersion of the ash samples and diluted with air in a multi-stage dilution system. The ash particles were first dispersed by using a magnetic stirrer in a $100 \mathrm{ml}$ glass vessel that was purged with $500 \mathrm{ml} \mathrm{min}^{-1}$ of dry clean compressed laboratory air, and then diluted further in two stages by approximately 1:100 with dry air. The resulting aerosol had a geometric mean diameter of 1.4$1.6 \mu \mathrm{m}$, a geometric standard deviation between 1.6-1.7 $\mu \mathrm{m}$, and a number density ranging between 15-21 ash particles $\mathrm{cm}^{-3}$. Particles were collected from the aerosol flow using the same electrostatic precipitator and sampling conditions as for the measurement of ambient aerosol. Sample sizes were between 10 and 60 liters of air. The sample flow rate was $21 \mathrm{~min}^{-1}$ of air. The aerosol particle (AP) size spectra and number density were measured by a TSI 3321 Aerodynamic Particle Sizer (APS), and a TSI 3007 Condensation Particle Counter (CPC), respectively.

\section{Atmospheric ice nuclei during spring 2010}

\subsection{IN number concentration}

In our record of 965 individual daily IN measurements at TO from April 2008 to March 2010 the ice nucleus number concentration (at $-18^{\circ} \mathrm{C}$ and water saturation) ranges between 1.3 and $312 \mathrm{IN}^{-1}$, with a median of $24.2 \mathrm{IN}^{-1}$ (Klein, 2010; Klein et al., 2010b). Figure 1 shows the IN number concentration recorded at TO during the spring of 2010, with the seasonal mean and standard deviation of $45 \pm 54 \mathrm{IN}^{-1}$ (arithmetic mean \pm standard deviation) for the months of April-June 2008-2010 indicated by the blue line and vertical bar (pink bands), respectively. The Eyjafjallajökull eruption began on 14 April 2010 and ended on 21 May (Schumann et al., 2011). During the first days of the eruption a high pressure system was located west of the British Isles. The volcanic plume was carried in a northwesterly descending flow within 1-2 days straight across the North Sea towards central Europe, where it resided for several days. When the plume was advected over Europe the highest IN peaks obtained so far in our record were detected, which significantly exceed the seasonal background at the site. According to dispersion models, trajectory calculations (Fig. 2), and ceilometer observations of the German Meteorological Sevice DWD the plume reached central Germany in the afternoon of 16 April (Emeis et al., 2010). This was confirmed by sun photometer observations at Leipzig (Ansmann et al., 2010). The IN number concentration at TO began to rise at 15:00 UTC on 16 April, peaked at 10:30 (UTC) on 17 April, and remained high until 21 April. The aerosol lidars at Leipzig and $\mathrm{Mu}-$ nich (Ansmann et al., 2010) observed pronounced volcanic 


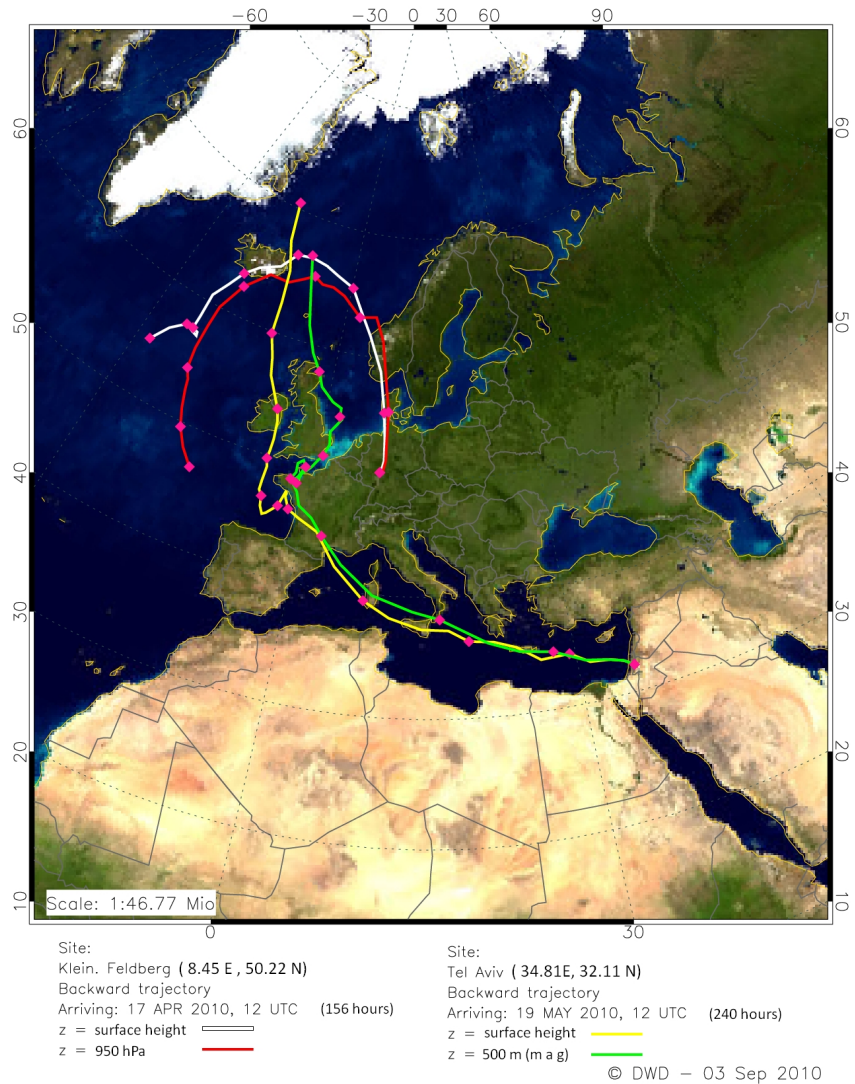

Fig. 2. Backward trajectories from Eyjafjallajökull volcano arriving at Taunus Observatory in April 2010 and at Tel Aviv in May 2010. Trajectories were calculated by the German Weather Service DWD.

ash layers throughout the free troposphere from 16-24 April 2010. The peak of $641 \mathrm{IN}^{-1}$ on April 17 clearly exceeds the highest peak of $312 \mathrm{IN}^{-1}$ obtained previously during an intense Sahara dust episode of May 2008 (Klein et al., 2010b). The fraction of aerosol activated as ice nuclei at $-18^{\circ} \mathrm{C}$ and $119 \% \mathrm{rh}_{\text {ice }}$ is $4.7 \times 10^{-1} \pm 1.32 \times 10^{-1}$ (standard error of mean, $n=16$, Table 1), based on 16 IN samples and APS data during the peaks of 16-22 April. The corresponding area density of ice-active sites per aerosol surface is $5.05 \times 10^{10} \mathrm{~m}^{-2} \pm 1.28 \times 10^{10} \mathrm{~m}^{-2}$ (standard error of mean, $n=16$ ). Both quantities are considerably higher than what we observed in Saharan dust over Europe in May 2008. Aged volcanic ash was present over central Europe during much of the second half of the month of April, and this was extensively characterized by aircraft measurements (Schumann et al., 2011) and Lidar measurements (Flentje et al., 2010). Our daily IN measurements at TO also reflect this in the relatively high monthly mean of $69 \mathrm{IN}^{-1}$ for April 2010, as compared to the previous years (April 2008: $46 \mathrm{INl}^{-1}$; April 2009: $18 \mathrm{IN}^{-1}$ ). High IN concentrations of $100-256 \mathrm{IN}^{-1}$ were again recorded at TO on 16 and 17 May. For both days the presence of volcanic ash over central Europe is demonstrated by Schumann et al. (2011) from the results of various ash de-

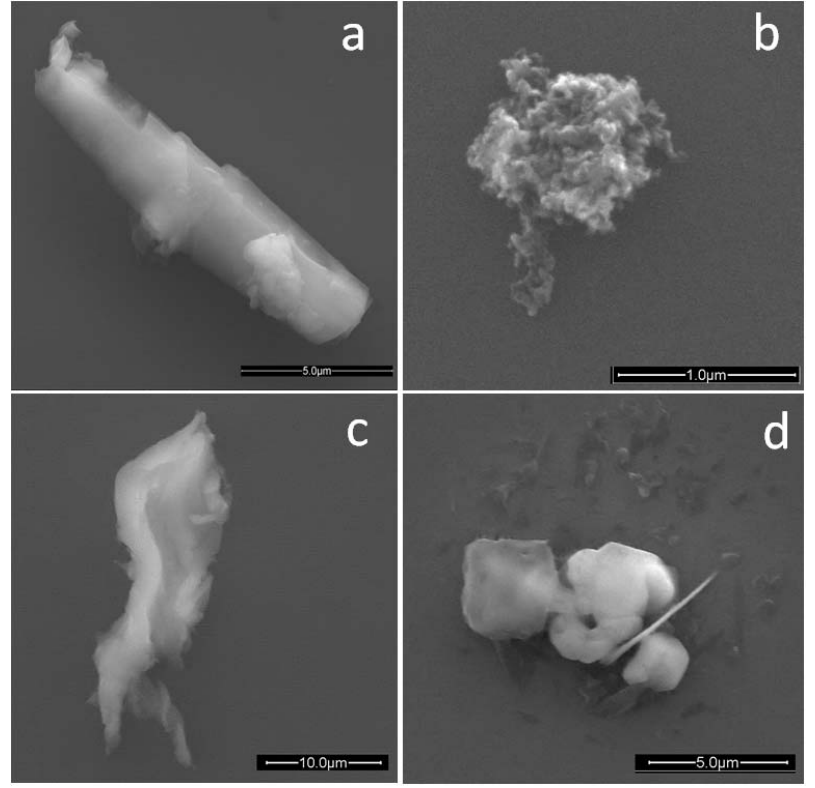

Fig. 3. Secondary electron images by ESEM of various ice nuclei that were previously identified by FRIDGE: (a) volcanic particle; (b) soot; (c) biological particle; (d) sea salt.

tection systems such as satellite and airborne Lidar measurements and by model predictions of the Volcanic Ash Advisory Center.

A significant volcanic contribution to IN was also recorded a month later at Tel Aviv, more than $5000 \mathrm{~km}$ away from the source. Tel Aviv is frequently affected by dust storms, due to the proximity to Arabian and African deserts. During such conditions (defined by a daily average $\mathrm{PM}_{10}$ concentration higher than $100 \mu \mathrm{g} \mathrm{m}^{-3} ; 37$ cases), the concentrations of $\mathrm{PM}_{10}$ and of IN at $-18^{\circ} \mathrm{C}$ (mean \pm standard error) in October 2009 were $273.9 \pm 35.5 \mu \mathrm{g} \mathrm{m}^{-3}$ and $53.7 \pm 7.2 \mathrm{IN}^{-1}$, as compared to $41.3 \pm 0.9 \mathrm{\mu g} \mathrm{m}^{-3}$ and $27.4 \pm 2.0 \mathrm{IN}^{-1}$, respectively, during the "clean" days (with $\mathrm{PM}_{10}$ daily average $<60 \mu \mathrm{g} \mathrm{m}^{-3} ; 109$ cases). During 18-23 May 2010, the trajectories (Fig. 2) suggest the advection of air from the north eastern Atlantic around Iceland towards the eastern Mediterranean. While the $\mathrm{PM}_{10}$ measurements at TAU during these days indicate "clean" conditions, with $\mathrm{PM}_{10}$ values well below the $100 \mu \mathrm{g} \mathrm{m}^{-3}$ level (defined as a dust event), the IN peak at around $100 \mathrm{l}^{-1}$ (see Fig. 5) and the average of $66.9 \pm 37.5 \mathrm{IN}^{-1}$ (5 samples) is significantly higher than the averages for both normal "clean" days and for some "dusty" days. Furthermore, the elemental composition of individual particles that were randomly selected from the samples collected during the passage of the volcanic plume over Israel was analyzed using ESEM-EDX. The analysis shows that the volcanic particles had similar composition to mineral dust, except that sea salt and some sulphate were also present. All these observations clearly point to a significant contribution 
Table 1. Deposition nucleation properties of Eyjafjallajökull volcanic aerosol collected from ambient air, from laboratory generated aerosol of ash sample Ey0, and of Saharan dust aerosol; AP = Aerosol particles.

\begin{tabular}{|c|c|c|c|c|}
\hline sample & Reference & $\begin{array}{l}\text { Analyzing } \\
\text { conditions }\end{array}$ & $\begin{array}{l}\text { Activated fraction } \\
\text { \# IN/\# AP }\end{array}$ & $\begin{array}{l}\text { IN surface } \\
\text { density \# } \mathrm{m}^{-2}\end{array}$ \\
\hline Ambient aerosol, 16-22 April volcanic peak & This work & $-18^{\circ} \mathrm{C}, 119 \% \mathrm{rh}_{\text {ice }}$ & $4.70 \times 10^{-1}$ & $5.05 \times 10^{10}$ \\
\hline Ey0 volcanic ash sample, lab., & This work & $-18^{\circ} \mathrm{C}, 119 \% \mathrm{rh}_{\text {ice }}$ & $5.98 \times 10^{-5}$ & $6.0 \times 10^{6}$ \\
\hline Ey0 volcanic ash sample, lab. & Hoyle et al. (2011), Fig.7 & $-25^{\circ} \mathrm{C}, 100-125 \% \mathrm{rh}_{\text {ice }}$ & $1-2 \times 10^{-4}$ & \\
\hline Ey0 volcanic ash sample, lab. & Steinke et al. (2011), Figs. 7, 8 & $-31^{\circ} \mathrm{C}, 120-128 \%$ & & $4 \times 10^{8}-10^{10}$ \\
\hline Ambient aerosol Saharan dust episode & Klein et al. (201b) & $-18^{\circ} \mathrm{C}, 119 \% \mathrm{rh}_{\text {ice }}$ & $4 \times 10^{-4}$ & $1.1 \times 10^{9}$ \\
\hline
\end{tabular}

Table 2. Relative number abundances [\%] and $95 \%$ confidence intervals (in parenthesis) of the different particle groups among IN collected from the atmosphere during the volcanic ash events on 17 April and 17 May 2010.

\begin{tabular}{lrrrr}
\hline Particle group & $\begin{array}{r}\text { Sample \#905 } \\
04 / 17 / 10(n=95)^{*}\end{array}$ & $\begin{array}{c}\text { Sample \#906 } \\
04 / 17 / 10(n=44)^{*}\end{array}$ & $\begin{array}{r}\text { Sample \#945 } \\
05 / 16 / 10(n=50)^{*} 05 / 17 / 10(n=50)^{*}\end{array}$ & Sample \#948 \\
\hline Volcanic ash & $52.6(35.2-66.2)$ & $56.8(31.9-75.1)$ & $66.0(41.3-84.3)$ & $68.0(43.1-82.9)$ \\
Sea salt & $11.6(5.2-23.8)$ & $11.4(3.6-30.8)$ & $20.0(7.1-45.0)$ & $26.0(12.8-45.7)$ \\
Soot & $13.7(6.6-26.3)$ & $20.5(8.6-41.2)$ & $0.0(0.0-20.1)$ & $2.0(0.2-16.8)$ \\
Biological & $9.5(3.9-21.2)$ & $0.0(0.0-15.1)$ & $12.0(3.2-36.1)$ & $4.0(0.7-19.7)$ \\
C-rich & $3.2(0.5-16.8)$ & $2.3(0.2-25.6)$ & $0.0(0.0-20.1)$ & $0.0(0.0-20.1)$ \\
Metal/Metal Oxides & $8.4(2.6-24.0)$ & $9.1(1.9-34.5)$ & $0.0(0.0-20.1)$ & $0.0(0.0-20.1)$ \\
other & $1.1(0.1-13.5)$ & $0.0(0.2-22.2)$ & $2.0(0.1-23.2)$ & $0.0(0.0-20.1)$ \\
\hline
\end{tabular}

* Total number of particles.

of volcanic ash to the total IN population over Israel during this event.

\subsection{Composition of atmospheric IN}

239 particles were analyzed by ESEM/EDX in four aerosol samples collected at TO during the peaks of the volcanic ash event on 17 April and on 16-17 May. The relative number fractions of the different particle groups among the IN are shown in Table 2 and Fig. 4 (mean values for each ash event). Confidence intervals (95\%) were calculated assuming a multinomial distribution (for details see Weinbruch et al., 2002). In all four IN samples volcanic ash particles are the dominating particle group. In some of these samples also a high abundance of (aged) sea-salt, soot, and/or biological particles was encountered. While some biological material is known to have high IN efficiency, pure sea-salt and soot are generally regarded as inefficient IN (Pruppacher and Klett, 1997; Dymarska et al., 2006). Nevertheless, these particle groups were also found as IN in several other field campaigns and by other techniques (e.g. Twohy and Poellot, 2005; Pratt et al., 2009). Depending on the specific particle history in ambient air, the ice nucleating capabilities of a particulate component can be changed by surface reactions, coatings, and agglomeration during its atmospheric lifetime, as shown for example by Rosinski (1995) and Ebert et al. (2011).
The relative abundance of volcanic IN as fraction of all IN analyzed, $r_{\text {volc }}$, is $53 \%$ and $57 \%$, respectively, for the two samples from the first event, and $66 \%$ and $68 \%$, respectively, for the second event. Multiplication of $r_{\text {volc }}$ by the total atmospheric IN number concentration $n_{\text {tot }}$ measured by FRIDGE in these samples yields the number concentration of atmospheric volcanic IN, $n_{\mathrm{volc}}$, given in Table 3: $n_{\text {volc }}=r_{\text {volc }} \times n_{\text {tot }}$. To check the consistency between the measurements of IN composition and number concentration (by FRIDGE), $n_{\text {volc }}$ may be compared to an estimate $\Delta n$ of the excess of IN in the plume above the ambient IN background $n_{\text {bg. }} . \Delta n$ is given by $\Delta n=n_{\text {tot }}-n_{\text {bg }}$ (Table 3 ). As background value $n_{\text {bg }}$ we take the seasonal mean IN number concentration for the months of April through June of 2008 and 2009, which is $45 \pm 54 \mathrm{IN}^{-1}$ (mean \pm std. deviation, $n=210)$. Between $57 \%$ and $72 \%\left(n_{\text {volc }} / \Delta n\right.$ in Table 3 , means for each sample) of the excess-IN number concentration $\Delta n$ can be explained as volcanic during the first event, and $100 \%$ for the samples of the second event.

Thus, while the particle analysis clearly shows the importance of the Eyjfjallajökull event for the high IN concentrations encountered at Kleiner Feldberg, the data indicate that the abundance of volcanic ash particles does not explain the increased IN concentration completely in the first event. The wide range of a possible volcanic contribution $n_{\mathrm{vol}} / \Delta n$ in Table 3 results partly from a combination of errors in the 
Table 3. Estimated atmospheric number concentrations of volcanic IN based on particle analysis versus peak enhancement of IN above background in volcanic plume.

\begin{tabular}{lllll}
\hline $\begin{array}{l}\text { Property } \\
\text { (unit) }\end{array}$ & $\begin{array}{l}\text { Sample \#905 } \\
04 / 17 / 10(n=95)^{\mathrm{a}}\end{array}$ & $\begin{array}{l}\text { Sample \#906 } \\
04 / 17 / 10(n=44)^{\mathrm{a}}\end{array}$ & $\begin{array}{l}\text { Sample \#945 } \\
05 / 16 / 10(n=50)^{\mathrm{a}}\end{array}$ & $\begin{array}{l}\text { Sample \#948 } \\
05 / 17 / 10(n=50)^{\mathrm{a}}\end{array}$ \\
\hline$n_{\text {tot }}\left(\# 1^{-1}\right)$ & $641(561-721)^{\mathrm{b}}$ & $214(187-241)$ & $109(95-123)$ & $135(118-152)$ \\
$r_{\text {volc }}(\%)$ & $52.6(35.2-66.2)$ & $56.8(31.9-75.1)$ & $66.0(41.3-84.3)$ & $68.0(43.1-82.9)$ \\
$n_{\text {volc }}\left(\# 1^{-1}\right)$ & $337(226-424)$ & $122(68-161)$ & $72(45-92)$ & $92(58-112)$ \\
$\Delta n\left(\# 1^{-1}\right)$ & $596(499-693)^{\mathrm{c}}$ & $169(109-229)$ & $64(8-120)$ & $90(33-147)$ \\
$n_{\text {volc }} / \Delta n(\%)$ & $57(38-75)^{\mathrm{d}}$ & $72(34-110)$ & $113(8-218)$ & $102(31-173)$ \\
\hline
\end{tabular}

$n_{\text {tot }}=$ total IN number concentration by FRIDGE; $r_{\mathrm{volc}}=$ volcanic ash $\%$ fraction by ESEM; $n_{\mathrm{volc}}=$ number concentration of volcanic IN; $n_{\mathrm{volc}}=r_{\mathrm{volc}} \times n_{\mathrm{tot}} ; \Delta n=$ number concentration of excess IN; $\Delta n=n_{\text {tot }}-n_{\mathrm{bg}}$; ${ }^{\mathrm{a}}$ total number of particles analysed by ESEM/EDX; ${ }^{\mathrm{b}}$ range derived by applying $12.5 \%$ measurement error (Klein et al., $2010 \mathrm{a}$ ); ${ }^{\mathrm{c}}$ Gaussian error of $n_{\text {tot }}$ plus $n_{\text {bg }}$; ${ }^{\mathrm{d}}$ Gaussian error of $n_{\text {volc }}$ plus $\Delta n$.

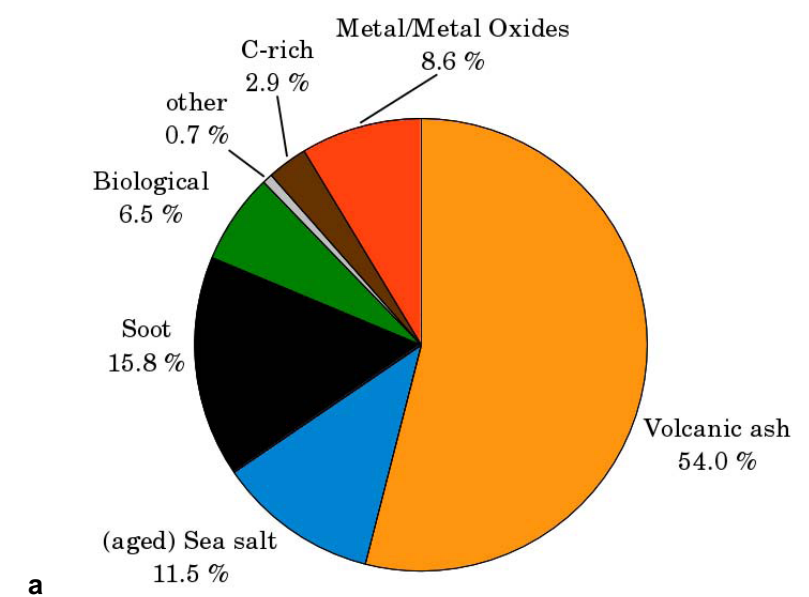

$\mathbf{a}$

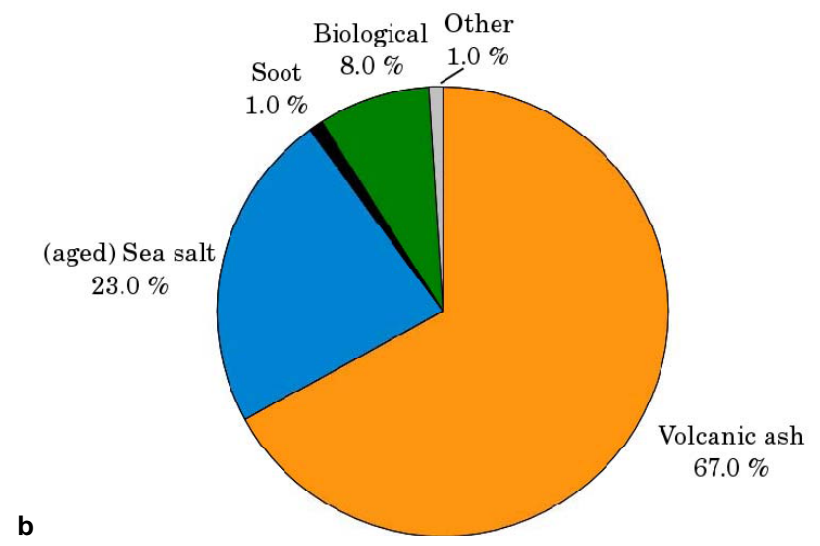

Fig. 4. Average relative number abundance of different particle groups among ice nuclei at TO during volcanic ash events: (a) April (samples \#905 and \#906) and (b) May (samples \#945 and \#948). individual FRIDGE and ESEM measurements, as well as from the assumed background $n_{\mathrm{bg}}$. However, there may also be additional systematic sources of error in the classification of particles that are not covered by our confidence intervals of Table 2. As small inclusions of volcanic material were detected within individual sea salt and soot particles these particles may have partly a volcanic origin. Furthermore, some of the Fe-rich particles within the metal/metal oxide group may also be volcanic particles. Therefore, the volcanic ash contribution to the IN may be significantly higher. Presumably, additional effects that are currently not well understood have added to the increased $n_{\text {tot }}$ concentration. For example the high abundance of soot and metal/oxides in the IN fraction during the April events (samples 905 and 906) points to anthropogenic influences. As will be shown below, some aging, transformation, internal mixing or selection processes seem to increase the ice nucleating ability of the volcanic ash during its transport in the atmosphere. Therefore, it seems conceivable that not all the IN are recognized as volcanic ash in the electron microscopic analysis.

The abundance of soil material within the volcanic ash group is assumed to be lower than $10 \%$. The average Si/Alratio in the additional impactor samples collected on boron substrates (see Sect. 2) was 3.2. This is almost identical to the measurements of Gislason et al. (2010) in bulk ash samples from Eyjafjallajökull, whereas it has been found during a previous study to be always lower than 3 for northern and northwestern air masses arriving at TO (Ebert et al., 2004). Pristine as well as aged Saharan dusts also show lower Si/Al ratios of around 2 (Kandler et al., 2007, 2009). Furthermore, also the iron, magnesium, calcium and titanium concentrations in the additional impactor samples agree with the values given by Gislason et al. (2010). Together with the results of the airmass trajectory analysis (Fig. 2) this clearly indicates the dominating role of volcanic material at the time of sampling at Taunus Observatory. 


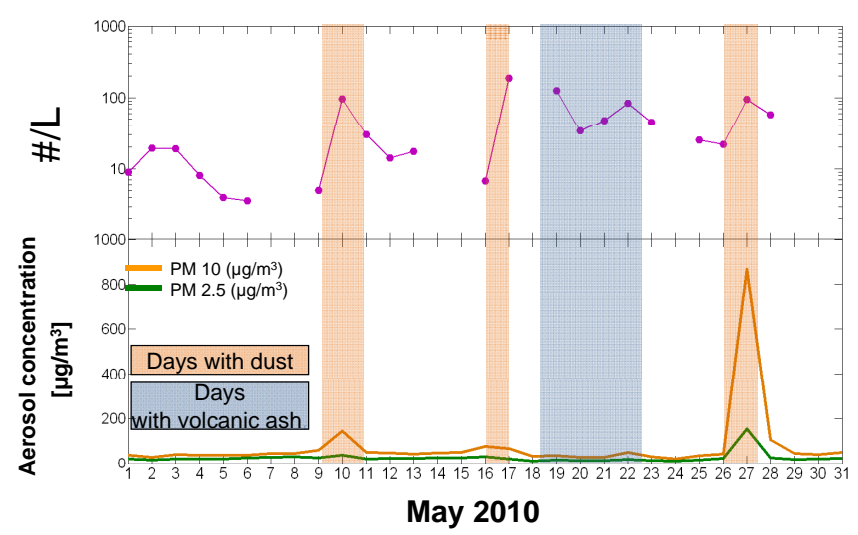

Fig. 5. Number concentration of ice nuclei (at $-18^{\circ} \mathrm{C}$ and water saturation) and concentration of particulate matter below $10 \mu \mathrm{m}$ diameter $\left(\mathrm{PM}_{10}\right)$ and below $2.5 \mu \mathrm{m}\left(\mathrm{PM}_{2.5}\right)$ at Tel Aviv University during May 2010.

\section{Ice nucleating properties of dispersed volcanic ash}

Aerosol was generated by dry dispersion of particles from the Ey0 and Ey1 samples that had been analyzed previously by Hoyle et al. (2011) and Steinke et al. (2011). In 13 individual runs from sample Ey0 and three runs from sample Ey1 the IN and particle number density were measured by FRIDGE, APS and CPC. Particle number densities measured by CPC and APS agreed to within $20 \%$ on average.

\subsection{Activated fraction}

Overall, the nucleating efficiency of all samples was found to be rather poor. In four of the 13 Ey0 samples and in one of the Ey1 samples no IN were detectable above background noise. For the remaining 11 runs with IN counts above background the mean activated fraction (i.e. IN number density/aerosol number density by APS) at $-18^{\circ} \mathrm{C}$ is $5.98 \times 10^{-5} \pm 1.7 \times 10^{-5}$ (std error of mean, $n=9$ ) for the Ey0 sample (Table 1) and $2.7 \times 10^{-4}(n=2)$ for Ey1. During one of the Ey0 runs the aerosol was sampled in parallel by both FRIDGE and our IN counter FINCH (Bundke et al., 2008), a continuous flow mixing chamber which grows ice on airborne nuclei and detects it while suspended in air. The FINCH measurements yield an activated fraction of $2.7 \times 10^{-5}$ at $-16^{\circ} \mathrm{C}$ and $100-120 \% \mathrm{rh}_{\text {ice }}$ and in general confirm the FRIDGE data. The overall range of activation of around $2.7 \times 10^{-5}$ to $5.98 \times 10^{-5}$ observed in our measurements on the Ey0 sample is thus even slightly lower than the $1-2 \times 10^{-4}$ given by Hoyle et al. (2011) for Ey0 at $-15^{\circ} \mathrm{C}, 100-120 \% \mathrm{rh}_{\text {ice }}$, but agrees well if the slightly different temperatures and different setup of both experiments are considered. These activated fractions are in sharp contrast to the $4.70 \times 10^{-1}$ derived from our IN and APS field measurements at the Taunus Observatory, when the volcanic ash cloud was present.

\subsection{Ice-active site density}

The number density of ice-active sites per aerosol surface area $n_{\text {dep }}\left(\mathrm{IN} \mathrm{m}^{-2}\right)$ from our IN and APS measurements of the Ey0 test aerosol at $-18^{\circ} \mathrm{C}$ is $n_{\text {dep }}=6.0 \times 10^{6} \mathrm{IN}$ $\mathrm{m}^{-2} \pm 1.9 \times 10^{6} \mathrm{IN} \mathrm{m}^{-2}$ (standard error of mean, $n=9$ ). Again this figure is more than 3 orders of magnitude lower than the $n_{\text {dep }}=5.1 \times 10^{10} \mathrm{~m}^{-2}$ that we derive from our measurements on the ambient aerosol over the Taunus Observatory during the volcanic event (Table 1). From their measurements of deposition nucleation on the Ey0 dust sample in the AIDA cloud chamber Steinke et al. (2011) find a strong dependence of $n_{\text {dep }}$ on temperature, however in a very different temperature regime $\left(-49^{\circ} \mathrm{C}\right.$ to $\left.-31^{\circ} \mathrm{C}\right)$. At $-31^{\circ} \mathrm{C}$ their $n_{\text {dep }}$ is approximately $4 \times 10^{8} \mathrm{~m}^{-2}$. In the range covered by our measurements, between -8 to $-18^{\circ} \mathrm{C}$, Steinke et al. (2011) observed no contribution of deposition freezing.

\section{Discussion}

The signal of volcanic ash in our record of atmospheric IN at TO after the air masses had travelled for at least $2200 \mathrm{~km}$ is surprisingly pronounced. The IN number density $\left(\right.$ at $\left.-18^{\circ} \mathrm{C}\right)$ in samples collected under the volcanic plume was enhanced by approximately a factor of 9 against the seasonal background of 2009, suggesting a major volcanic contribution. For an activation temperature of $-8^{\circ} \mathrm{C}$ this factor is 6.5. The electron microscopic analysis of individual ice-nucleating particles in these samples confirms that volcanic ash particles were the dominating particle group, although others were present too. However, laboratory nucleation experiments on ash samples collected in the vicinity of the eruption site (Hoyle et al., 2011; Steinke et al., 2011), as well as conclusions drawn from these data, argue against a significant volcanic contribution to IN abundance. Hoyle et al. (2011) derive IN number densities of around $11^{-1}$ to $101^{-1}$ for the best IN (immersion and deposition modes) in the ash plume, by scaling their laboratory results to the conditions in the ash plume as measured over Central Europe from aircraft (Schumann et al., 2011) and over Switzerland by Lidar (Wienhold, 2012), and by applying some microphysical considerations. These IN number densities are more than an order of magnitude lower than our IN measurements at Taunus Observatory, although the former apply to temperatures more that $17^{\circ} \mathrm{C}$ lower than our measurements. The apparent discrepancy that exists between our IN field measurements and the nucleation experiments of Hoyle et al. (2011) and Steinke et al. (2011) on volcanic ash is confirmed by our own analysis of the same ash samples, which again shows the rather poor ice nucleating properties of the ash collected close to the eruption site. At $-18^{\circ} \mathrm{C}, 119 \% \mathrm{rh}_{\text {ice }}$, both the fraction of aerosol activated as ice nuclei and the ice-active site density of the aerosol are three orders of magnitude larger in the samples collected at TO from ambient air during the volcanic peak than in the aerosolized Ey0 ash sample. Methodical differences cannot account for this, since we applied the same 
methods (FRIDGE and APS) for our analysis of both the collected ash and the ambient air samples. However, the ash samples have a history and grain size (Hoyle et al., 2011) that is different from that of our atmospheric samples. While the Ey0 sample and our ambient air samples of 17 April both relate to approximately the same early eruption phase at around 15 April, the Ey0 sample was deposited shortly after eruption, whereas the latter have been transported and processed for around 2 days in the plume and in clouds. The obviously very different nucleating properties of fresh and of aged volcanic dust point to a positive, so far unspecified effect of atmospheric aging and potentially of cloud processing, that increases the ice nucleating properties of volcanic aerosol during long-range transport. Thus, while current knowledge would suggest that coatings of the particles with sulfuric acid and water would reduce the nucleating efficiency of the particles, the differences between the nucleating properties of the aerosolized ash and the ambient aerosol point into the opposite direction. Atmospheric processing and aging necessarily incorporates other materials (soot, salts, and other) into the volcanic dust aerosol. This effect may indeed explain why our analysis of IN composition accounts only 53-68\% of the particles to pure volcanic ash. Such an effect of aging might also shed light on the so far inconclusive and conflicting observational evidence that is available from the literature on volcanic ice nuclei. Most of the evidence for volcanic ice nuclei comes from measurements that were made far away from the sources, whereas the evidence against it comes predominantly from measurements nearby the source. Isono et al. (1959) found at Tokyo, Japan, the concentration of IN (at $-20^{\circ} \mathrm{C}$ ) to increase to up to $50 \mathrm{IN}^{-1}$ above the $5-20 \mathrm{IN}^{-1}$ background in air that had been affected by Japanese volcanoes located $110-1180 \mathrm{~km}$ upwind. Conversely, Price and Pales (1963) and Hobbs et al. (1971) found no evidence for enhanced IN in volcanic effluents, when they sampled on the slopes of Mauna Loa, Hawaii. Measurements in the vicinity of volcanos from aircraft in the plumes of St. Augustine, Alaska (Schnell and Delany, 1976) and of Mt. Baker, Washington (Radke et al., 1976) also found no evidence for IN of volcanic origin. Some of the latter results were debated recently because the situations sampled were considered more representative for passively degassing volcanoes rather than for large explosive eruptions and because of a postulated underestimation of IN by the technique applied (Durant et al., 2008; Pruppacher and Klett, 1997). Recently Prenni et al. (2009) reported IN number concentrations in the free troposphere over the Arctic from aircraft measurements in all nucleation modes (except contact nucleation) with a continuous flow diffusion chamber. One of their flights encountered more than $50 \mathrm{INl}^{-1}$, much above the average background, that was below $2 \mathrm{IN}^{-1}$. In this case, the back trajectory suggested that the air had passed several days ago directly over the active volcano Shiveluch in Kamchatka. The chemical composition of the IN was considered to be generally consistent with volcanic ash composition.
The highest temperature at which we processed atmospheric samples in FRIDGE was $-8^{\circ} \mathrm{C}$. The growth of ice was observed in each of the samples analyzed at this temperature and at water saturation. We cannot exclude the existence of ice nuclei active at even warmer temperatures than $-8^{\circ} \mathrm{C}$. The number of IN active at $-8^{\circ} \mathrm{C}$ was on average $34 \%$ of the number counted at $-18^{\circ} \mathrm{C}$ and water saturation. Such a high freezing temperature compares well with laboratory measurements of bulk volcanic ash from Kilauea, Hawaii and Cerro Hudson, Chile, by Durant et al. (2008) and from Mount St.Helens (Schnell et al., 1982). From a synthesis of their own laboratory data and historical data Durant et al. (2008) conclude "that volcanic ash particles initiate freezing in a relatively narrow temperature range of approximately $250 \mathrm{~K}$ to $260 \mathrm{~K}$ (or perhaps up to $265 \mathrm{~K}$ )". Durant et al. (2008) and Schnell et al. (1982) measured in the immersion and contact freezing modes, whereas our measurements address the deposition and condensation-freezing modes. However the high rates of clouds glaciation observed at a temperature as warm as $-15{ }^{\circ} \mathrm{C}$ during the presence of the Eyjafjallajökull ash over Europe (Seifert et al., 2011) argue for the ice-nucleating effectiveness of aged volcanic aerosol.

At a cloud glaciation temperature as high as $-8^{\circ} \mathrm{C}$ (equivalent to $3.5 \mathrm{~km}$ altitude in the Standard Atmosphere) the Eyjafjallajökull volcanic event may have affected even lower tropospheric clouds by glaciogenic seeding. While midlevel stratus normally is considered to play a neutral role in the Earth's radiation budget, because it reflects about as much shortwave solar radiation as it absorbs terrestrial radiation (Cotton, 2009), the quantitative effects of massive cloud seeding on both budget entries remains an unresolved question. Considering the high effectiveness of aged Eyjafjallajökull particles as IN and the large areal extent of marine stratus and altostratus with possible supercooling in the high northern latitudes (Bretherton and Hartmann, 2009; Hartmann, 1994), a large scale natural cloud seeding event might have taken place, with possible consequences for cloud radiative forcing. In view of the quasi-permanent emission of fine ash particles into the atmosphere by small volcanic eruptions around the globe the results of our work demand for more studies on the mechanisms and effects of aging of this aerosol on its ice nucleating properties, as well as on the global volcanic source of IN as a whole.

Acknowledgements. We thank C. R. Hoyle and I. Steinke for providing the Ey0 and Ey1 volcanic ash samples. We thank the German Weather Service DWD for providing the trajectory analysis. This work was funded by Deutsche Forschungsgemeinschaft (DFG) under the Collaborative Research Centre SFB 641 and the Research Unit FOR 1525, the German Israeli Foundation for Scientific Research and Development (GIF), and the Virtual Institute "Aerosol-Cloud-Interactions" of the Helmholtz-Gemeinschaft.

Edited by: G. Pappalardo 


\section{References}

Ansmann, A., Tesche, M., Groß, S., Freudenthaler, V., Seifert, P., Hiebsch, A., Schmidt, J., Wandinger, U., Mattis, I., Müller, D., and Wiegner, M.: The 16 April 2010 major volcanic ash plume over central Europe: EARLINET lidar and AERONET photometer observations at Leipzig and Munich, Germany, Geophys. Res. Lett., 37, L13810, doi:10.1029/2010GL043809, 2010.

Belosi, F., Santachiara, G., and Prodi, F.: Eyjafjallajökull volcanic eruption: ice nuclei and particle characterization, Atmos. Climate Sciences, 1, 48-54, 2011.

Bretherton, C. S. and Hartmann, D. L.: Large-scale control on cloudiness, in: Clouds in the Perturbed Climate System, edited by: Heintzenberg, J. and Charlson, R. J., MIT Press, Cambridge, MA, 217-234, 2009.

Bundke, U., Nillius, B., Jaenicke, R., Wetter, T., Klein, H., and Bingemer, H.: The fast ice nucleus chamber FINCH, Atmos. Res. 90, 180-186, 2008.

Choi, Y.-S. Lindzen, R. S., Ho, C.-H., and Kim, J.: Space observations of cold-cloud phase change, P. Natl. Acad. Sci. USA, 107, 11211-11216, 2010

Cotton, W. R.: Weather and climate engineering, in: Clouds in the Perturbed Climate System, edited by: Heintzenberg, J. and Charlson, R. J., MIT Press, Cambridge, 339-367, 2009.

DeMott, P. J., Möhler, O., Stetzer, O., Vali, G., Levin, Z., Petters, M. D., Murakami, M., Leisner, Th., Bundke, U., Klein, H., Kanji, Z. A., Cotton, R., Jones, H., Benz, S., Brinkmann, M., Rzesanke, D., Saathoff, H., Nicolet, M., Saito, A., Nillius, B., Bingemer, H., Abbatt, J. P. D., Ardon, K., Ganor, E., Georgakopoulos, D. G., and Saunders, C.: Resurgence in ice nuclei measurement research, B. Am. Meteor. Soc., 92, 1623-1635, doi:10.1175/2011BAMS3119.1, 2011.

Durant, A. J., Shaw, R. A., Rose, W. I., Mi, Y., and Ernst, G. G. J.: Ice nucleation and overseeding of ice in volcanic clouds, J. Geophys. Res., 113, D09206, doi:10.1029/2007JD009064, 2008.

Dymarska, M., Murray, B. J., Sun, L., Eastwood, M. L., Knopf, D. A., and Bertram, A. K.: Deposition ice nucleation on soot at temperatures relevant for the lower troposphere, J. Geophys. Res. Atmos., 111, D04204, doi:10.1029/2005JD006627, 2006.

Ebert, M., Weinbruch, S., Hoffmann, P., and Ortner, H. M.: Chemical Characterization of North Sea Aerosol Particles by Total Reflection X-Ray Fluorescence Analysis and High-Resolution Scanning Electron Microscopy, J.Aerosol Sci., 31, 613-632, 2000.

Ebert, M., Weinbruch, S., Hoffmann, P., and Ortner, H. M.: The chemical characterization and complex refractive index of rural and urban influenced aerosols determined by individual particle analysis, Atmos. Environ., 38, 6531-6545, 2004.

Ebert, M., Worringen, A., Benker, N., Mertes, S., Weingartner, E., and Weinbruch, S.: Chemical composition and mixing-state of ice residuals sampled within mixed phase clouds, Atmos. Chem. Phys., 11, 2805-2816, doi:10.5194/acp-11-2805-2011, 2011.

Emeis, S., Junkermann, W., Schäfer, K., Forkel, R., Suppan, P., Flentje, H., Gilge, S., Fricke, W., Wiegner, M., Freudenthaler, V., Groß, S., Ries, L., Meinhardt, F., Münkel, C., and Obleitner, F.: Spatial structure and dispersion of the 16/17 April 2010 volcanic ash cloud over Germany, Atmos. Chem. Phys. Discuss., 10, 26117-26155, doi:10.5194/acpd-10-26117-2010, 2010.

Flentje, H., Claude, H., Elste, T., Gilge, S., Köhler, U., PlassDülmer, C., Steinbrecht, W., Thomas, W., Werner, A., and
Fricke, W.: The Eyjafjallajökull eruption in April 2010 - detection of volcanic plume using in-situ measurements, ozone sondes and lidar-ceilometer profiles, Atmos. Chem. Phys., 10, 1008510092, doi:10.5194/acp-10-10085-2010, 2010.

Gasso, S.: Satellite observations of the impact of weak volcanic activity on marine clouds, J. Geophys. Res., 113, D14S19, doi:10.1029/2007JD009106, 2008.

Gislason, S. R., Hassenkam, T., Nedel, S., Bovet, N., Eiriksdottir, E. S., Alfredsson, H. A., Hem, C. P., Balogh, Z. I., Dideriksen, K., Oskarsson, N., Sigfusson, B., Larsen, G., and Stipp, S. L. S.: Characterization of Eyjafjallajökull volcanic ash particles and a protocol for rapid risk assessment, P. Natl. Acad. Sci., 18, 73077312, 2010.

Hartmann, D. L.: Global Physical Climatology, Academic Press, San Diego, CA, 411 pp., 1994.

Hobbs, P. V., Fullerton, C. M., and Bluhm, G. C.: Ice nucleus storms in Hawaii, Nature, 230, 90-91, 1971.

Hoyle, C. R., Pinti, V., Welti, A., Zobrist, B., Marcolli, C., Luo, B., Höskuldsson, Á., Mattsson, H. B., Thorsteinsson, T., Larsen, G., and Peter, T.: Ice nucleation properties of volcanic ash from Eyjafjallajökull, Atmos. Chem. Phys. Discuss., 11, 17201-17243, doi:10.5194/acpd-11-17201-2011, 2011.

Isono, K., Komabayasi, M., and Ono, A.: The nature and origin of ice nuclei in the atmosphere, J. Meteorol. Soc. Japan, 37, 211232, 1959.

Kandler K., Benker, N., Bundke, U., Cuevas, E., Ebert, M., Knippertz, P., Rodríguez, G. S., Schütz, L., and Weinbruch, S.: Chemical composition and complex refractive index of Saharan Mineral Dust at Izaña, Tenerife (Spain) derived by electron microscopy, Atmos. Environ., 41, 8058-8074, 2007.

Kandler K., Schütz, L., Deutscher, C., Hofmann, H., Jäckel, S., Knippertz, P., Lieke, K.,Maßling, A., Schladitz, A., Weinzierl, B., Zorn, S., Ebert, M., Jaenicke, R., Petzold, A., and Weinbruch, S.: Size distribution, mass concentration, chemical and mineralogical composition, and derived optical parameters of the boundary layer aerosol at Tinfou, Morocco, during SAMUM 2006, Tellus B, 61, 32-50, doi:10.1111/j.16000889.2008.00397.x, 2009.

Klein, H.: Variabilität der Eiskeimkonzentration über Zentraleuropa, Ph.D. dissertation, Goethe-University, Frankfurt am Main, 143 pp., 2010.

Klein, H., Haunold, W., Bundke, U., Nillius, B., Wetter, T., Schallenberg, S., and Bingemer, H.: A new method for sampling of atmospheric ice nuclei with subsequent analysis in a static diffusion chamber, Atmos. Res., 96, 218-224, 2010a.

Klein, H., Nickovic, S., Haunold, W., Bundke, U., Nillius, B., Ebert, M., Weinbruch, S., Schuetz, L., Levin, Z., Barrie, L. A., and Bingemer, H.: Saharan dust and ice nuclei over Central Europe, Atmos. Chem. Phys., 10, 10211-10221, doi:10.5194/acp10-10211-2010, 2010b.

Langer, G. and Rodgers, J.: An experimental study of the detection of ice nuclei on membrane filters and other substrata, J. Appl. Meteorol., 14, 560-570, 1975.

Mather, T. A., Pyle, D. M., and Oppenheimer, C.: Tropospheric volcanic aerosol, In: Volcanism and the Earth's Atmosphere, Geophysical Monograph, 139, 189-211, 2003.

Möhler, O., DeMott, P. J., Vali, G., and Levin, Z.: Microbiology and atmospheric processes: the role of biological particles in cloud physics, Biogeosciences, 4, 1059-1071, doi:10.5194/bg-4-1059- 
2007, 2007.

Möhler, O., DeMott, P. J., Stetzer, O., the ICIS-2007 team: The Fourth International Ice Nucleation Workshop ICIS-2007. Proceedings to the 15 th International Conference on Clouds and Precipitation, Cancun, Mexico, 7-11 July, 2008.

Pratt, K. A., DeMott, P. J., French, J. R., Wang, Z., Westphal, D. L., Heymsfield, A. J., Twohy, C. H., Prenni, A. J., and Prather, K. A.: In situ detection of biological particles in cloud ice-crystals, Nature Geosci., 2, 398-401, 2009.

Prenni, A. J., DeMott, P. J., Rogers, D. C., Kreidenweis, S. M., McFarquhar, G. M., Zhang, G., and Poellot, M. R.: Ice nuclei characteristics from M-PACE and their relation to ice formation in clouds, Tellus, 61B, 436-448, 2009.

Price, S. and Pales, J. C.: Local volcanic activity and ice nuclei concentrations on Hawaii, Arch. Met. Geoph. Biokl. A., 13, 398407, 1963.

Pruppacher, H. R. and Klett, J. D.: Microphysics of Clouds and Precipitation, Kluwer, Dordrecht, 2nd edition, 1997.

Radke, L. F., Hobbs, P. V., and Stith, J. L.: Airborne measurements of gases and aerosols from volcanic vents on Mt. Baker, Geophys. Res. Lett., 3, 93-96, 1976.

Robock, A.: Volcanic eruptions and climate, Rev. Geophys., 38, 191-220, 2000.

Rosinski, J.: Cloud condensation nuclei as a real source of ice forming nuclei in continental and marine air masses, Atmos. Res., 38, 351-359, 1995.

Schnell, R. C. and Delany, A. C.: Airborne ice nuclei near an active volcano, Nature, 264, 535-536, 1976.

Schnell, R. C., Pueschel, R. F., and Wellman, D. L.: Ice nucleus characteristics of Mount St. Helens effluents, J. Geophys. Res., 87, 11109-11112, 1982.

Schumann, U., Weinzierl, B., Reitebuch, O., Schlager, H., Minikin, A., Forster, C., Baumann, R., Sailer, T., Graf, K., Mannstein, H., Voigt, C., Rahm, S., Simmet, R., Scheibe, M., Lichtenstern, M., Stock, P., Rüba, H., Schäuble, D., Tafferner, A., Rautenhaus, M., Gerz, T., Ziereis, H., Krautstrunk, M., Mallaun, C., Gayet, J.-F., Lieke, K., Kandler, K., Ebert, M., Weinbruch, S., Stohl, A., Gasteiger, J., Groß, S., Freudenthaler, V., Wiegner, M., Ansmann, A., Tesche, M., Olafsson, H., and Sturm, K.: Airborne observations of the Eyjafjalla volcano ash cloud over Europe during air space closure in April and May 2010, Atmos. Chem. Phys., 11, 2245-2279, doi:10.5194/acp-11-2245-2011, 2011.
Seifert, P., Ansmann, A., Groß, S., Freudenthaler, V., Heinold, B., Hiebsch, A., Mattis, I., Schmidt, J., Schnell, F., Tesche, M., Wandinger, U., and Wiegner, M.: Ice formation in ashinfluenced clouds after the eruption of the Eyjafjallajökull volcano in April 2010, J. Geophys. Res., 116, D00U04, doi:10.1029/2011JD015702, 2011.

Steinke, I., Möhler, O., Kiselev, A., Niemand, M., Saathoff, H., Schnaiter, M., Skrotzki, J., Hoose, C., and Leisner, T.: Ice nucleation properties of fine ash particles from the Eyjafjallajökull eruption in April 2010, Atmos. Chem. Phys., 11, 12945-12958, doi:10.5194/acp-11-12945-2011, 2011.

Szyrmer, W. and Zawadsky, I.: Biogenic and anthropogenic sources of ice-forming nuclei: A review, B. Am. Meteorol. Soc., 78, 209228, 1997.

Twohy, C. H. and Poellot, M. R.: Chemical characteristics of ice residual nuclei in anvil cirrus clouds: evidence for homogeneous and heterogeneous ice formation, Atmos. Chem. Phys., 5, 22892297, doi:10.5194/acp-5-2289-2005, 2005.

Weinbruch S., van Aken P., Ebert M., Thomassen Y., Skogstad A., Chashchin V. P., and Nikonov, A.: The heterogeneous composition of working place aerosols in a nickel refinery: a transmission and scanning electron microscope study, J. Environ. Monit., 4, 344-350, 2002.

Wienhold, F.: Measurements and analysis of the Eyjafjöllajökull plume optical properties over Switzerland in April 2010, Atmos. Chem. Phys. Discuss., in preparation, 2012. 